\title{
Natalizumab may control immune checkpoint inhibitor-induced limbic encephalitis
}

\author{
Andreas F. Hottinger, MD, PhD, Rita de Micheli, MD, * Vanessa Guido, MD, * Alexandra Karampera, MD,* \\ Patric Hagmann, MD, PhD,* and Renaud Du Pasquier, MD
}

Neurol Neuroimmunol Neuroinflamm March 2018;5:e439. doi:10.1212/NXI.0000000000000439

\author{
Correspondence \\ Dr. Hottinger \\ Andreas.hottinger@gmail.com
}

In recent years, new therapeutic approaches that restore the ability of the immune system to attack cancer cells have dramatically improved the outcome of various malignant tumors, including melanoma and lung cancer. Ipilimumab, a monoclonal antibody that binds and inhibits cytotoxic T-lymphocyte-associated antigen 4, and nivolumab, a monoclonal antibody that blocks programmed cell-death protein 1, have been approved. As these treatments, respectively, block $\mathrm{T}$-cell inhibition and potentiate the activation of $\mathrm{T}$ cells, they may trigger a number of neurologic immune-related adverse events, ${ }^{1-9}$ as illustrated here.

We describe a 71-year-old woman who was diagnosed in 2014 with stage IV small-cell lung cancer and treated with 6 cycles of cisplatin/etoposide, followed by mediastinal and prophylactic cranial irradiation. Because of tumor progression in the lung and liver, she received a first dose of nivolumab $1 \mathrm{mg} / \mathrm{kg}$, followed by ipilimumab $3 \mathrm{mg} / \mathrm{kg}$. On day 4 following administration, she developed short-term memory deficits that worsened over the next 5 days. On admission, she was found to be disoriented in time and space and unable to recall any word after 5 minutes. Autobiographic memory was preserved. She presented dysexecutive disorder and was unable to read or write. MRI showed severe abnormalities in both hippocampi with contrast-enhancing lesions (figure, A and B). A lumbar puncture showed lymphocytic pleocytosis (white blood cells: 16 cells $/ \mu \mathrm{L} ; 87 \%$ lymphocytes, $12 \%$ monocytes, and $1 \%$ neutrophils, and increased CSF protein $[1,145 \mathrm{mg} / \mathrm{L}])$. Cytologic examination showed no evidence of malignant cells. Extensive evaluation of blood and CSF revealed no evidence of infection. The CSF was positive for anti-HU antibodies as well as for an uncharacterized antibody against Purkinje cells. It was negative for other antibodies including CASPR2, recoverin, Sox1, Titin, Zic4, DNER/Tr, amphiphysin, CV2/CRMP5, Ma2/Ta (PNMA2), Ri, Yo, GAD65, NMDAR, GABAR, IgLON5, AMPAR2, DPPX, LGI1, glycine receptor, and mGluR5. Nivolumab and ipilimumab were discontinued, and the patient was treated with high-dose IV methylprednisolone $(1,000 \mathrm{mg})$. After 5 days, steroids were progressively tapered off; the patient, however, showed new clinical deterioration requiring introduction of natalizumab and a new temporary increase in steroids. Thereafter, steroids could be weaned off completely, and the patient showed neurologic improvement within 2 months of starting natalizumab as well as marked improvement of the MRI findings (figure, C and D). The patient is now able to recall $3 / 5$ words at 5 minutes and can read and write. It is important to note that despite having received a single dose of nivolumab/ipilimumab, the patient showed a durable oncologic response.

This case illustrates several key points: (1) As evidenced by the presence of anti-Hu antibodies, this patient had autoimmune encephalitis, which was likely exacerbated by the hyperactivation of $\mathrm{T}$ cells, induced by nivolumab/ipilimumab: The timing of the onset of neurologic symptoms strongly suggests an immune-related adverse event. ${ }^{10}$ Indeed, 3 other cases of paraneoplastic encephalitis that developed early, i.e., within days of initiation of immune checkpoint inhibitors, 
Figure Immune checkpoint inhibitor-induced encephalitis before and after treatment with natalizumab
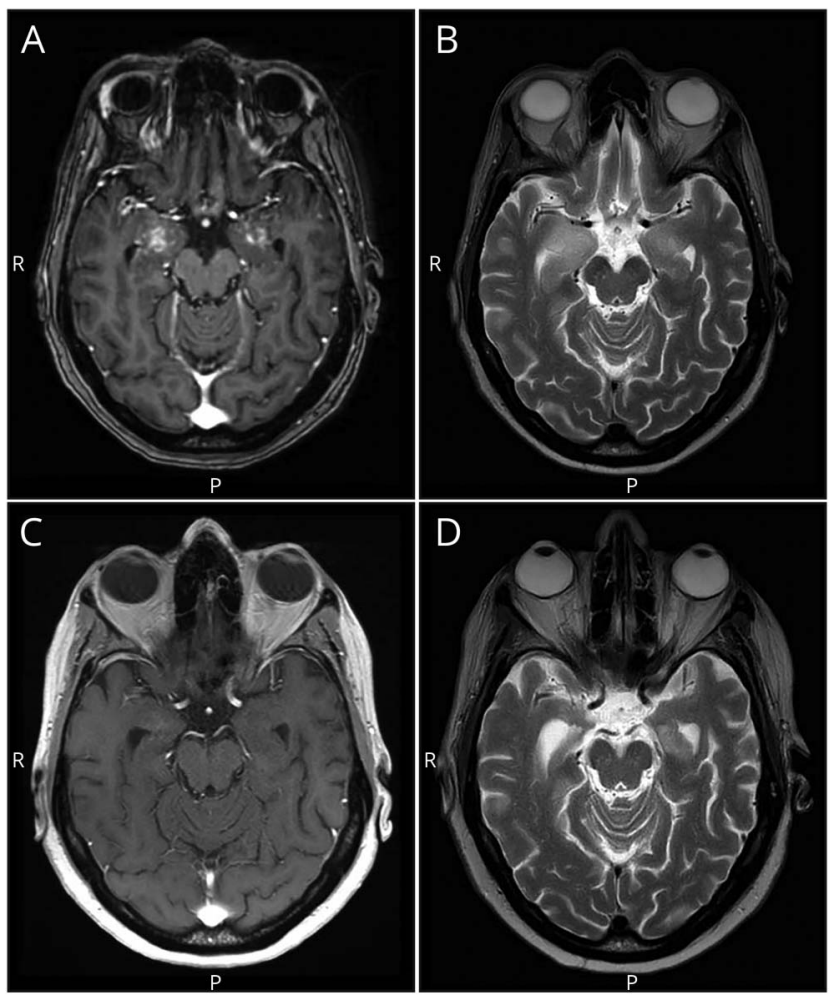

A 71-year-old woman was diagnosed in 2014 with small-cell lung cancer. In 2016, she was treated with nivolumab and ipilimumab for systemic recurrence. Four days later, she developed severe disorientation and shortterm memory deficits. Brain MRI shows bilateral contrast-enhancing lesions with associated T2 hyperintensity of the hippocampi (A and B). The images normalize after 6 months of treatment with natalizumab ( $C$ and $D)$.

were described. ${ }^{1,4}$ (2) Paraneoplastic encephalitis may present with gadolinium enhancement on MRI. ${ }^{11}$ (3) Early recognition and treatment with immune-suppressive agents are essential, as these patients may show marked improvement. (4) More importantly, these side effects are typically controlled by high-dose steroids that act as potent immune suppressors; however, steroids might also block the response of the checkpoint inhibitors against cancer, thus impeding the advantages that are precisely expected with the latter drugs. ${ }^{4}$ Natalizumab, a drug used for treating multiple sclerosis and Crohn disease, ${ }^{12}$ might be an ideal drug to control paraneoplastic encephalitis induced by immune checkpoint inhibitors: it is directed against the subunit $\alpha 4$ from $a 4 \beta 1$ and $a 4 b 7$ integrins. Yet, these integrins, expressed at the surface of lymphocytes, bind to vascular cell adhesion molecule- 1 and mucosal vascular addressin cell adhesion molecule-1, which are expressed on endothelial cells of the blood-brain and blood-gut barriers, respectively. This interaction decreases leukocyte adhesion, attachment, and migration across these barriers. ${ }^{13}$ However, the immune response in other compartments is not impeded. Therefore, we hypothesize that, in our case, administration of natalizumab contributed to decrease the CNS inflammation without compromising the immune reaction against systemic localizations of the cancer and therefore allowed for continuation of immune checkpoint inhibitor therapy, despite the development of paraneoplastic encephalitis. In our patient, we believe that natalizumab played a key role in controlling the autoimmune adverse event, as steroids could be tapered well before the end of the half-life of the checkpoint inhibitors. As these cases are extremely rare, we propose to set up a registry to collect data on the presenting symptoms, treatments, and outcomes of these patients.

\section{Author contributions}

Dr. Hottinger: study concept and design, acquisition of data, analysis and interpretation, critical revision of the manuscript for important intellectual content, and study supervision. Dr. de Micheli: acquisition of data, analysis and interpretation, and critical revision of the manuscript for important intellectual content. Dr. Guido and Dr. Karampera: acquisition of data and critical revision of the manuscript for important intellectual content. Dr. Hagmann and Prof. Du Pasquier: acquisition of data, analysis and interpretation, and critical revision of the manuscript for important intellectual content.

\section{Study funding}

No targeted funding reported.

\section{Disclosure}

A.F. Hottinger served on the scientific advisory board of Novocure and BMS; received travel funding from Novocure; and served on the speakers' bureau (funds provided to institution) of Novocure. R. de Micheli, V. Guido, A. Karampera, and P. Hagmann report no disclosures. R. Du Pasquier served on the scientific advisory board of Biogen, Genzyme, Merck, and Novartis; received travel funding and/or speaker honoraria from Sanofi, Genzyme, and Rochel; served on the editorial board of Neurovirology; and received research support from the Swiss National Foundation and the Swiss Society for Multiple Sclerosis, Novartis. Go to Neurology.org/NN for full disclosure forms.

Received August 31, 2017. Accepted in final form November 13, 2017.

\section{References}

1. Williams TJ, Benavides DR, Patrice KA, et al. Association of autoimmune encephalitis with combined immune checkpoint inhibitor treatment for metastatic cancer. JAMA Neurol 2016;73:928-933.

2. Hottinger AF. Neurologic complications of immune checkpoint inhibitors. Curr Opin Neurol 2016;29:806-812

3. Cuzzubbo S, Javeri F, Tissier M, et al. Neurological adverse events associated with immune checkpoint inhibitors: review of the literature. Eur J Cancer 2017;73:1-8.

4. Larkin J, Chmielowski B, Lao CD, et al. Neurologic serious adverse events associated with nivolumab plus ipilimumab or nivolumab alone in advanced melanoma, including a case series of encephalitis. Oncologist 2017;22:709-718.

5. Royal RE, Levy C, Turner $\mathrm{K}$, et al. Phase 2 trial of single agent Ipilimumab (anti-CTLA-4) for locally advanced or metastatic pancreatic adenocarcinoma. J Immunother 2010;33:828-833.

6. Kao JC, Liao B, Markovic SN, et al. Neurological complications associated with anti-programmed death 1 (PD-1) antibodies. JAMA Neurol 2017;74:1216-1222.

7. Feng S, Coward J, McCaffrey E, Coucher J, Kalokerinos P, O’Byrne K. Pembrolizumab induced encephalopathy: a review of neurological toxicities with immune checkpoint inhibitors. J Thorac Oncol 2017;12:1626-1635. 
8. Schneider S, Potthast S, Komminoth P, Schwegler G, Böhm S. PD-1 checkpoint inhibitor associated autoimmune encephalitis. Case Rep Oncol 2017;10: 473-478.

9. Ito M, Fujiwara S, Fujimoto D, et al. Rituximab for nivolumab plus ipilimumab-induced encephalitis in a small-cell lung cancer patient. Ann Oncol 2017;28:2318-2319.

10. Darnell RB, Posner JB. Paraneoplastic syndromes involving the nervous system. N Engl J Med 2003;349:1543-1554.
11. Oyanguren B, Sánchez V, González FJ, et al. Limbic encephalitis: a clinicalradiological comparison between herpetic and autoimmune etiologies. Eur J Neurol 2013;20:1566-1570.

12. Keeley KA, Rivey MP, Allington DR. Natalizumab for the treatment of multiple sclerosis and Crohn's disease. Ann Pharmacother 2005;39:1833-1843.

13. Lobb RR, Hemler ME. The pathophysiologic role of alpha 4 integrins in vivo. J Clin Invest 1994;94:1722-1728. 


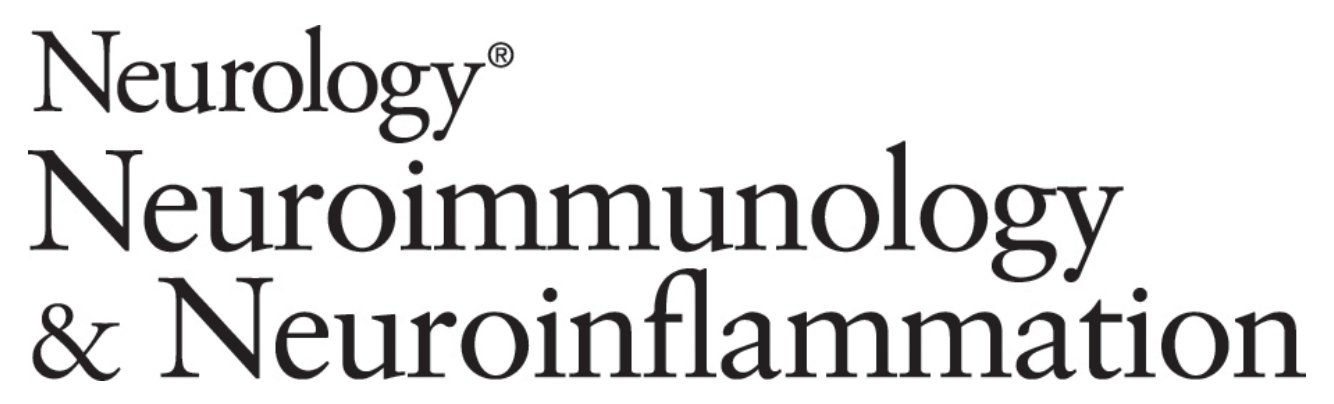

Natalizumab may control immune checkpoint inhibitor-induced limbic encephalitis Andreas F. Hottinger, Rita de Micheli, Vanessa Guido, et al.

Neurol Neuroimmunol Neuroinflamm 2018;5;

DOI 10.1212/NXI.0000000000000439

This information is current as of January 11, 2018

Neurol Neuroimmunol Neuroinflamm is an official journal of the American Academy of Neurology.

Published since April 2014, it is an open-access, online-only, continuous publication journal. Copyright

Copyright $\odot 2018$ The Author(s). Published by Wolters Kluwer Health, Inc. on behalf of the American

Academy of Neurology.. All rights reserved. Online ISSN: 2332-7812.

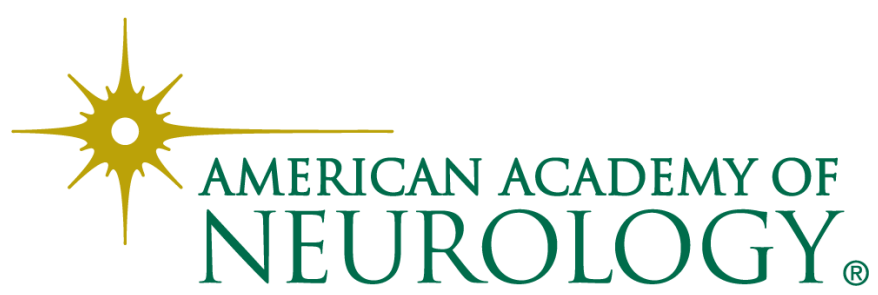




\section{Updated Information \& Services}

References

Citations

Subspecialty Collections

\section{Permissions \& Licensing}

Reprints including high resolution figures, can be found at: http://nn.neurology.org/content/5/2/e439.full.html

This article cites 13 articles, 1 of which you can access for free at: http://nn.neurology.org/content/5/2/e439.full.html\#\#ref-list-1

This article has been cited by 2 HighWire-hosted articles: http://nn.neurology.org/content/5/2/e439.full.html\#\#otherarticles

This article, along with others on similar topics, appears in the following collection(s):

\section{Autoimmune diseases}

http://nn.neurology.org//cgi/collection/autoimmune_diseases Metastatic tumor

http://nn.neurology.org//cgi/collection/metastatic_tumor

MRI

http://nn.neurology.org//cgi/collection/mri

Paraneoplastic syndrome

http://nn.neurology.org//cgi/collection/paraneoplastic_syndrome

Information about reproducing this article in parts (figures,tables) or in its entirety can be found online at:

http://nn.neurology.org/misc/about.xhtml\#permissions

Information about ordering reprints can be found online:

http://nn.neurology.org/misc/addir.xhtml\#reprintsus

Neurol Neuroimmunol Neuroinflamm is an official journal of the American Academy of Neurology.

Published since April 2014, it is an open-access, online-only, continuous publication journal. Copyright

Copyright $\odot 2018$ The Author(s). Published by Wolters Kluwer Health, Inc. on behalf of the American

Academy of Neurology.. All rights reserved. Online ISSN: 2332-7812.

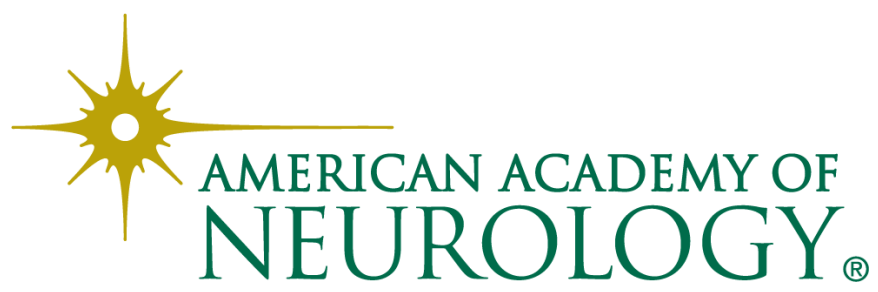

